OPEN ACCESS

Edited by:

Hongyue Dang,

Xiamen University, China

Reviewed by:

Lisa Y. Stein,

University of Alberta, Canada

James T. Hollibaugh,

University of Georgia, United States

${ }^{*}$ Correspondence:

Xin Sun

xins@princeton.edu

Specialty section:

This article was submitted to

Aquatic Microbiology,

a section of the journal

Frontiers in Microbiology

Received: 02 May 2017

Accepted: 12 June 2017

Published: 28 June 2017

Citation:

Sun $X$, Jayakumar $A$ and Ward $B B$

(2017) Community Composition of Nitrous Oxide Consuming Bacteria in the Oxygen Minimum Zone of the

Eastern Tropical South Pacific.

Front. Microbiol. 8:1183

doi: 10.3389/fmicb.2017.01183

\section{Community Composition of Nitrous Oxide Consuming Bacteria in the Oxygen Minimum Zone of the Eastern Tropical South Pacific}

\author{
Xin Sun*, Amal Jayakumar and Bess B. Ward \\ Department of Geosciences, Princeton University, Princeton, NJ, United States
}

The ozone-depleting and greenhouse gas, nitrous oxide $\left(\mathrm{N}_{2} \mathrm{O}\right)$, is mainly consumed by the microbially mediated anaerobic process, denitrification. $\mathrm{N}_{2} \mathrm{O}$ consumption is the last step in canonical denitrification, and is also the least $\mathrm{O}_{2}$ tolerant step. Community composition of total and active $\mathrm{N}_{2} \mathrm{O}$ consuming bacteria was analyzed based on total (DNA) and transcriptionally active (RNA) nitrous oxide reductase (nosZ) genes using a functional gene microarray. The total and active nos $Z$ communities were dominated by a limited number of nos $Z$ archetypes, affiliated with bacteria from marine, soil and marsh environments. In addition to nos $Z$ genes related to those of known marine denitrifiers, atypical nos $Z$ genes, related to those of soil bacteria that do not possess a complete denitrification pathway, were also detected, especially in surface waters. The community composition of the total nos $Z$ assemblage was significantly different from the active assemblage. The community composition of the total nos $Z$ assemblage was significantly different between coastal and off-shore stations. The low oxygen assemblages from both stations were similar to each other, while the higher oxygen assemblages were more variable. Community composition of the active nos $Z$ assemblage was also significantly different between stations, and varied with $\mathrm{N}_{2} \mathrm{O}$ concentration but not $\mathrm{O}_{2}$. Notably, nos $Z$ assemblages were not only present but also active in oxygenated seawater: the abundance of total and active nos $Z$ bacteria from oxygenated surface water (indicated by nos $Z$ gene copy number) was similar to or even larger than in anoxic waters, implying the potential for $\mathrm{N}_{2} \mathrm{O}$ consumption even in the oxygenated surface water.

Keywords: $\mathrm{N}_{2} \mathrm{O}$ consuming bacteria, nosZ gene, microarray, oxygen minimum zone, Eastern Tropical South Pacific

\section{INTRODUCTION}

$\mathrm{N}_{2} \mathrm{O}$ is a major ozone-depleting substance and a greenhouse gas whose radiative forcing per mole is 298 times that of carbon dioxide (IPCC, 2007; Ravishankara et al., 2009). Oxygen minimum zones (OMZs) are the most intense marine sources of $\mathrm{N}_{2} \mathrm{O}$ and are hot spots of rapid $\mathrm{N}_{2} \mathrm{O}$ cycling (Martinez-Rey et al., 2015). OMZs are marine regions with a strong $\mathrm{O}_{2}$ gradient (oxycline) overlying an oxygen deficient zone (ODZ) where $\mathrm{O}_{2}$ concentration is low enough to induce anaerobic processes. The global expansion and intensification of OMZs, which are 
predicted to result from global warming, further stress the importance of understanding $\mathrm{N}_{2} \mathrm{O}$ cycling in these regions (Codispoti, 2010). $\mathrm{N}_{2} \mathrm{O}$ production and consumption are driven by marine bacteria (Naqvi et al., 2000). The dominant microbial process for $\mathrm{N}_{2} \mathrm{O}$ cycling is denitrification, the sequential reduction of $\mathrm{NO}_{3}{ }^{-}$to $\mathrm{NO}_{2}{ }^{-}, \mathrm{NO}, \mathrm{N}_{2} \mathrm{O}$ and finally to $\mathrm{N}_{2}$ (Zumft, 1997; Naqvi et al., 2000). Denitrification could stop at an intermediate step before $\mathrm{N}_{2}$ if $\mathrm{O}_{2}$ concentration exceeds the threshold for the latter step or if electron donors are depleted (Ward et al., 2008; Dalsgaard et al., 2012; Babbin et al., 2014). Thus $\mathrm{O}_{2}$ concentration or electron donor availability could also control the $\mathrm{N}_{2} \mathrm{O}$ budget. $\mathrm{N}_{2} \mathrm{O}$ concentrations and net $\mathrm{N}_{2} \mathrm{O}$ production rates $\left(\mathrm{N}_{2} \mathrm{O}\right.$ production minus $\mathrm{N}_{2} \mathrm{O}$ consumption) were found to peak at the oxic-suboxic interface in OMZs, due to excess production from nitrification and incomplete denitrification (Nicholls et al., 2007; Ji et al., 2015; Trimmer et al., 2016). However, while multiple processes can produce $\mathrm{N}_{2} \mathrm{O}$, reduction by $\mathrm{N}_{2} \mathrm{O}$ consuming bacteria is the only known biological $\mathrm{N}_{2} \mathrm{O}$ sink.

$\mathrm{N}_{2} \mathrm{O}$ consumption is the final step of denitrification, and is the least $\mathrm{O}_{2}$ tolerant step (Bonin et al., 1989; Körner and Zumft, 1989). $\mathrm{N}_{2} \mathrm{O}$ consumption rates have been measured in ODZs at depths where $\mathrm{O}_{2}$ concentration ranged from very low to below the detection limit (Wyman et al., 2013; Babbin et al., 2015). $\mathrm{N}_{2} \mathrm{O}$ consumption by denitrification and genes involved in $\mathrm{N}_{2} \mathrm{O}$ reduction have also been detected in oxygenated seawater (Farías et al., 2009; Wyman et al., 2013). Characterizing the distribution and environmental regulation of this step is necessary for a complete quantification of the oceanic $\mathrm{N}_{2} \mathrm{O}$ budget and will improve our ability to predict oceanic $\mathrm{N}_{2} \mathrm{O}$ emissions under global climate change.

$\mathrm{N}_{2} \mathrm{O}$ consumption is catalyzed by the enzyme nitrous oxide reductase, encoded by the nos $Z$ gene. A recent study of nos $Z$ genes found a lower diversity of nos $Z$ genes in ODZ waters than in the upper oxycline of the OMZ (Castro-González et al., 2015). The distribution of nos $Z$ genes was related to $\mathrm{O}_{2}$ concentration, which suggested that the quantity and composition of nos $Z$ genes and the diversity of denitrifying bacteria might influence the microbial potential for $\mathrm{N}_{2} \mathrm{O}$ consumption.

We aimed to determine the distribution and community composition of total and transcriptionally active (abbreviated as 'active' hereafter) nos $Z$ assemblages based on the presence (DNA) and expression (RNA) of nosZ genes in the OMZ of the Eastern Tropical South Pacific (ETSP), one of the three major OMZs in the world ocean. Three hypotheses were tested in the study: (1) the community compositions of total and active nos $Z$ assemblages differ between coastal and off-shore stations because the quantity and quality of the nutrients at the two stations differ due to different contributions from land and sediment; (2) quantities and composition of total and active nos $Z$ assemblages are related to $\mathrm{O}_{2}$ concentration because $\mathrm{N}_{2} \mathrm{O}$ consumption is the least $\mathrm{O}_{2}$ tolerant step in conventional denitrification; and (3) the distribution of the active nos $Z$ assemblage is more related to $\mathrm{N}_{2} \mathrm{O}$ concentration than that of total nos $Z$ assemblage because the former indicates live and active organisms.

\section{MATERIALS AND METHODS}

\section{Experimental Sites and Sampling}

Samples were collected on the $R / V$ Nathaniel B. Palmer during June to July 2013 (cruise NBP 1305) in the OMZ of the ETSP at the off-shore station $\left(\mathrm{BB} 1 ; 14.0^{\circ} \mathrm{S}, 81.2^{\circ} \mathrm{W}\right)$ and the coastal station $\left(\mathrm{BB} 2 ; 20.50^{\circ} \mathrm{S}, 70.70^{\circ} \mathrm{W}\right.$ ) (Supplementary Figure 1). Particulate material was collected in Niskin bottles mounted on the standard conductivity-temperature-depth (CTD) rosette system (Seabird Electronics, Seattle, WA, United States) at four depths at each station (BB1: 60, 130, 300, and $1000 \mathrm{~m}$; BB2: 60, 115, 300, and $1000 \mathrm{~m}$ ) and concentrated by filtration (up to $4 \mathrm{~L}$ ) through Sterivex filters $(0.22 \mu \mathrm{m})$. Filters were flash frozen in liquid nitrogen onboard and stored at $-80^{\circ} \mathrm{C}$ until DNA and RNA extraction was performed.

Temperature, salinity, sigma theta, bottom depth and pressure at each station were measured on the SBE 911+ CTD system. Fluorescence, representing chlorophyll a, was measured using a single channel fluorometer (Wet labs, Philomath, OR, United States) mounted on the CTD. Oxygen distributions were determined using the STOX sensor (detection limit $=10 \mathrm{nM}$ ) mounted on the CTD rosette (Revsbech et al., 2009). Ammonium, nitrite and nitrate concentrations were measured using standard colorimetric protocols (UNESCO, 1994). $\mathrm{N}_{2} \mathrm{O}$ concentration was determined using mass spectrometry (Ji et al., 2015). $\mathrm{N}^{*}$ is the deviation of measured dissolved inorganic nitrogen $(\mathrm{DIN}=$ nitrate + nitrite + ammonia) from predicted DIN by Redfield ratio and the worldocean nitrogen to phosphate regression relationship (Deutsch et al., 2001). Environmental data were reported by Ji et al. (2015) and are provided in Supplementary Table 1.

\section{DNA and RNA Extractions}

Both DNA and RNA were extracted from eight Sterivex filters using the plant tissue protocol of the All Prep DNA/RNA Mini Kit (50) using a QIAcube (Qiagen). Reverse transcription from RNA to cDNA was performed using SuperScript ${ }^{\circledR}$ III FirstStrand Synthesis System for RT-PCR (Invitrogen ${ }^{\mathrm{TM}}$ by Life Technologies ${ }^{\mathrm{TM}}$ ). Excess RNA was removed by RNase at the end of the synthesis.

\section{Quantitative PCR Assays}

The abundance of total and active nos $Z$ assemblages were estimated by quantitative PCR (qPCR) using SYBR ${ }^{\circledR}$ Green based assays using protocols described previously (Jayakumar et al., 2013). Primers nosZ1F and nosZ1R (Henry et al., 2006) were used to amplify a 259-bp conserved fragment of the nos $Z$ gene. Known quantities ( $20-25 \mathrm{ng}$ ) of DNA and cDNA samples were assayed along with a minimum of five serial dilutions of plasmids containing nos $Z$ gene, no template controls and no primer controls, all in triplicate on the same plate. To maintain continuity and consistency among qPCR assays, a subset of samples from the first qPCR assay was run with subsequent assays and fresh standard dilutions were prepared for each assay. DNA, cDNA and the concentrated standards were quantified prior to every assay using PicoGreen fluorescence (Molecular Probes, 
Eugene, OR, United States) calibrated with several dilutions of phage lambda standards, to account for DNA loss due to freeze thaw cycles. qPCR assays were run on a Stratagene MX3000P (Agilent Technologies, La Jolla, CA, United States). Automatic analysis settings were used to determine the threshold cycle $(C t)$ values. The copy numbers (number of copies of the gene sequence detected in the sample) were calculated according to: Copy number $=(n g *$ number $/$ mole $) /(b p * n g / g * g /$ mole of $b p)$ and then converted to copy number per ml seawater filtered, assuming $100 \%$ extraction efficiency.

\section{Microarray Experiments}

DNA and cDNA qPCR products were used as targets for microarray experiments to characterize the community composition of total and active nos $Z$ assemblages, respectively. Triplicate qPCR products from each depth were pooled. nos $Z$ gene targets were purified and extracted from agarose gels using the QIAquick gel extraction kit (Qiagen). Purified DNA qPCR products from eight depths and cDNA qPCR products from seven depths were used to prepare targets for microarray analysis.

Microarray targets were prepared from the qPCR products following the protocol of Ward and Bouskill (2011). Briefly, dUaa was incorporated into purified DNA and cDNA during linear amplification using the BioPrime kit (Invitrogen ${ }^{\mathrm{TM}}$ ). The dUaa-Klenow product was labeled with Cy3 (dissolved in dimethyl sulfoxide), purified using QIAquick columns (Qiagen) and quantified by Nanodrop 2000 (Thermo Scientific). Duplicate $\mathrm{Cy} 3$ products for each sample were hybridized at $65^{\circ} \mathrm{C}$ overnight $(16 \mathrm{~h})$ onto replicate microarrays under ozone free conditions. Hybridized microarrays were washed and scanned with an Axon 4300 laser scanner.

\section{nosZ Microarray}

The microarray (BC016) contains 114 nos $Z$ archetype probes. Each probe is a 90 -bp sequence comprised of a 70-bp nos $Z$ gene fragment and a 20-bp control region. Each archetype probe represents, and hybridizes with, all nos $Z$ sequences with $>85 \%$ identity, based on published sequences available in 2013. There are 71 NosZ archetypes, which represent typical or Clade I nosZ genes, and 43 WNZ archetypes, which represent the atypical or Clade II nos $Z$ genes. The development of the microarray is described in Jayakumar et al. (in preparation) and the sequences are shown in Supplementary Table 2.

\section{Data Analyses}

Fluorescence signal intensities for nos $Z$ probes hybridized to the microarrays were obtained using GenePix Pro 7 software. The fluorescence ratio (FR) of each feature is defined as the ratio Cy3/Cy5 (70-mer probe/20-mer standard for each feature). The FR for each nos $Z$ archetype was calculated as the average of probe signal intensities for duplicate features on the same microarray. Normalized fluorescence ratio (FRn) was calculated by dividing the FR of each nos $Z$ probe by the maximum nos $Z$ FR on the same microarray. FRn is the proxy of the relative abundance of each archetype and was used for further analyses.
Detrended correspondence analysis (DCA) was performed to analyze the overall microbial community composition. A dissimilarity test was performed using Permutational Multivariate Analysis of Variance (adonis). $\alpha$-diversities (Shannon diversity indices) of total and active nos $Z$ assemblages were calculated. $\beta$-diversities (Bray-Curtis dissimilarities) of total and active nos $Z$ assemblages between different sites (i.e., depths) were calculated to perform a Mantel test. The Mantel test was used to determine significant environmental variables correlated with microbial community composition. These analyses were carried out using the vegan package in $\mathrm{R}$ (version 3.3.1). A maximum likelihood phylogenetic tree was built from aligned archetype sequences with MEGA 7 software. FRn values for each archetype at different depths from both stations were visualized on the phylogenetic tree by $\mathrm{iTOL}^{1}$. The copy number of nos $Z$ genes at each depth is given as mean ( \pm standard error) of the qPCR triplicates.

\section{RESULTS}

\section{Abundance and Depth Distribution of Total and Active nosZ Assemblages}

At stations $\mathrm{BB} 1$ and $\mathrm{BB} 2$, the continuously undetectable $\mathrm{O}_{2}$ concentration, the local nitrite maximum and the nitrate deficit at intermediate depths $(130-370 \mathrm{~m}$ at BB1; 75-400 $\mathrm{m}$ at BB2) all indicated the presence of ODZs (gray areas in Figure 1). Sampling depths were chosen to represent water column features defined by oxygen concentration, as measured with the in situ STOX sensor: oxygenated surface water, upper oxycline [characterized by sharp $\mathrm{O}_{2}$ concentration gradient ranging from saturation to below detection limit $(<10 \mathrm{nM})]$, top of the ODZ $\left(\mathrm{O}_{2}\right.$ concentration $\left.<10 \mathrm{nM}\right)$, core of the ODZ $\left(\mathrm{O}_{2}\right.$ concentration $<10 \mathrm{nM})$ and lower oxycline $\left(\mathrm{O}_{2}\right.$ concentration $>10 \mathrm{nM})$. The abundance of the total nos $Z$ genes ranged from $24.1( \pm 1.4)$ copies $\mathrm{mL}^{-1}$ in a sample from the lower oxycline to $636.4( \pm 28.3)$ copies $\mathrm{mL}^{-1}$ in a sample from the ODZ (Figure 1). As for the active nos $Z$ assemblage, the lowest abundance of active nos $Z$ genes was $5.1( \pm 0.5)$ copies $\mathrm{mL}^{-1}$ in a sample from the lower oxycline and the highest abundance was $604.6( \pm 103.7)$ copies $\mathrm{mL}^{-1}$ in a sample from the surface water.

The abundance of total and active nos $Z$ assemblages showed different distribution patterns at the two stations (Figure 1). At station $\mathrm{BB} 1$, the abundance of both total and active nos $Z$ genes was highest in a sample from the surface water, and decreased with depth. At station BB2, the abundance of both total and active nos $Z$ genes peaked in samples from the ODZ and was lowest in samples from the lower oxycline. The active nos $Z$ genes were most abundant in the sample from $300 \mathrm{~m}$. However, the total nos $Z$ genes were most abundant in the sample from $115 \mathrm{~m}$, where the abundance of the active nos $Z$ genes was only $3 \%$ of the total.

\footnotetext{
${ }^{1}$ http://itol.embl.de/
} 

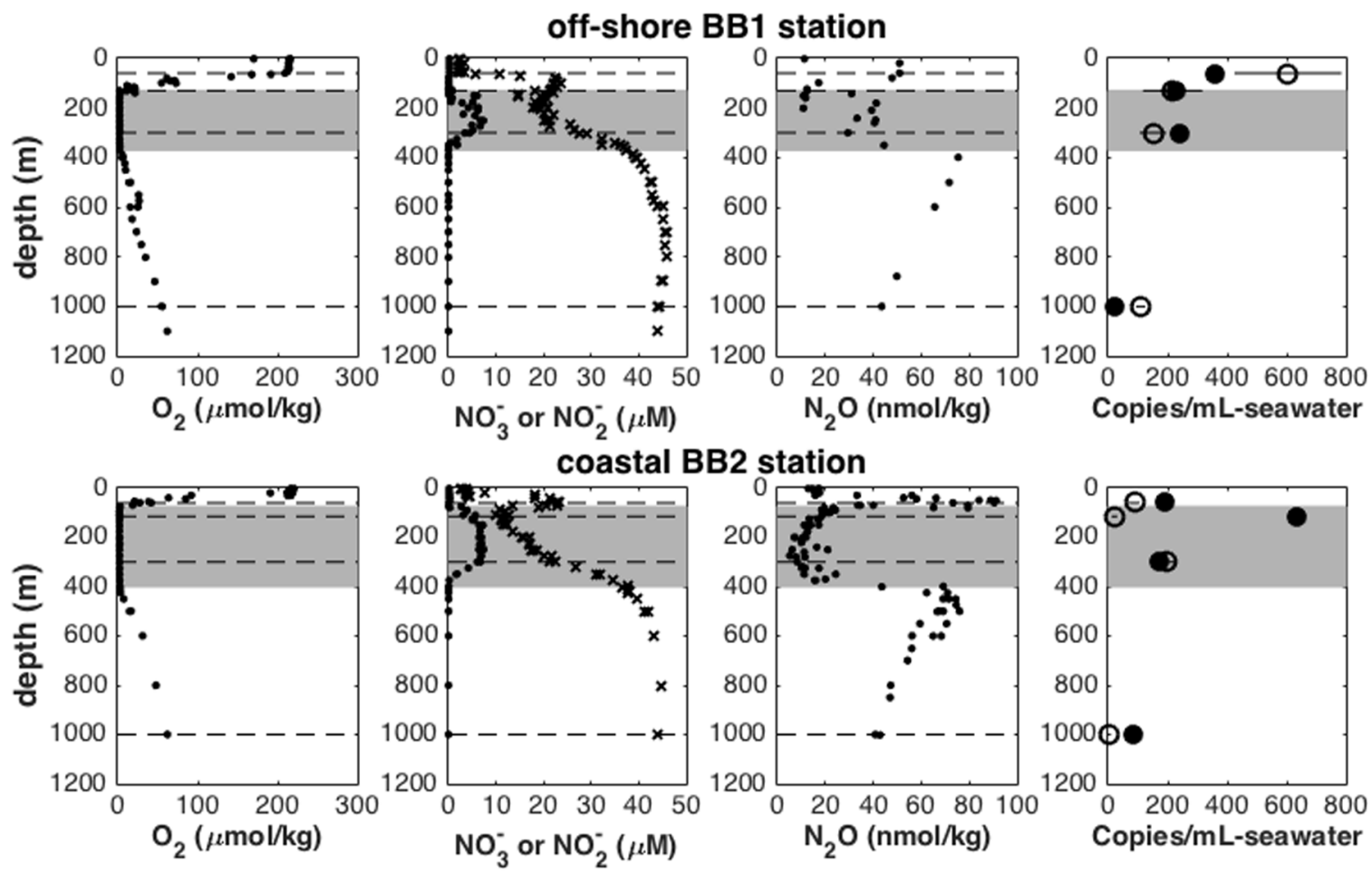

FIGURE $1 \mid \mathrm{O}_{2}, \mathrm{NO}_{3}{ }^{-}(\mathrm{x}), \mathrm{NO}_{2}{ }^{-}, \mathrm{N}_{2} \mathrm{O}$ and copy number of total (DNA, filled circles) and active (RNA, open circles) profiles at off-shore station BB1 and coastal station BB2. Dashed lines indicate depths where samples were collected. Gray areas indicate ODZs.

\section{Diversity and Dominant Archetypes of Total and Active nosZ Assemblages}

The distribution of FRn of the total or active archetypes was similar across all depths within the same station (Figure 2). The average $\alpha$-diversity was not significantly different (student's $t$-test, $P=0.102$ ) between the total assemblages (3.21) and the active assemblages (2.60) (Table 1). The least diverse total assemblage was from the lower oxycline (1000 $\mathrm{m}$ of station BB2), but the two least diverse active assemblages were from the ODZs (130 m of $\mathrm{BB} 1$ and $300 \mathrm{~m}$ of BB2).

The FRn distribution of nos $Z$ archetypes showed that a very limited number of archetypes dominated the total or the active nos $Z$ assemblages (Figure 2). Dominant archetypes were affiliated with bacteria from various environments, including salt marsh, soil, marine sediment, marine hot spring and activated sludge of a wastewater treatment plant (Supplementary Tables 3, 4). The FRn of the top five most abundant archetypes accounted for 48.9 to $83.3 \%$ of the total nos $Z$ hybridization signal (Figure 3A and Supplementary Table 3). Notably, the highest percentage $(83.3 \%)$ was from the sample from the lower oxycline $(1000 \mathrm{~m})$ at station BB2 and the most abundant archetype (NosZ42, an uncultured clone of nos $Z$ gene derived from salt marsh sediments; Kearns et al., 2015) accounted for $31.6 \%$ of total FRn. However, this archetype was not among the top five archetypes of the active nos $Z$ assemblage in the same sample (Figure 3B and Supplementary Table 4). The two most dominant typical nos $Z$ archetypes in the total assemblage were NosZ6, derived from an uncultured clone from salt marsh sediments (Kearns et al., 2015), which is closely related to Marinobacter, and NosZ65, derived from Marinobacter sp. BSs20148 from marine sediment (Song et al., 2013) (Figure 3A and Supplementary Table 3). In contrast, NosZ6 and NosZ65 were not dominant in the active assemblage (Figure $\mathbf{3 B}$ and Supplementary Table 4).

The sample from the ODZ $(130 \mathrm{~m})$ at station BB1 illustrates the contrasts observed between total and active nos $Z$ assemblages. The FRns of the top three dominant archetypes (WNZ21, WNZ16 and NosZ65) in the total nosZ assemblage were comparable to each other, and they constituted $56.1 \%$ of the total community (Supplementary Table 3). However, NosZ65 was nearly undetectable in the active assemblage and the top two dominant archetypes (WNZ21 and WNZ16) accounted for 87.8\% of the active assemblage in the same sample (Supplementary Table 4). The total nos $Z$ assemblage was much more diverse than the active assemblage at this depth (Table 1). The representative sequences of WNZ21 and WNZ16 archetypes were derived from nos $Z$ gene sequences of Anaeromyxobacter dehalogenans strain DCP18 (Chee-Sanford et al., unpublished) and an uncultured bacterium clone obtained from agricultural soils (Sanford et al., 2012), respectively. WNZ21 and WNZ16 archetypes were not only dominant in the active assemblage in one sample from the ODZ, but were among the top five abundant archetypes of both total and active assemblages in almost all samples (Figure 3). 


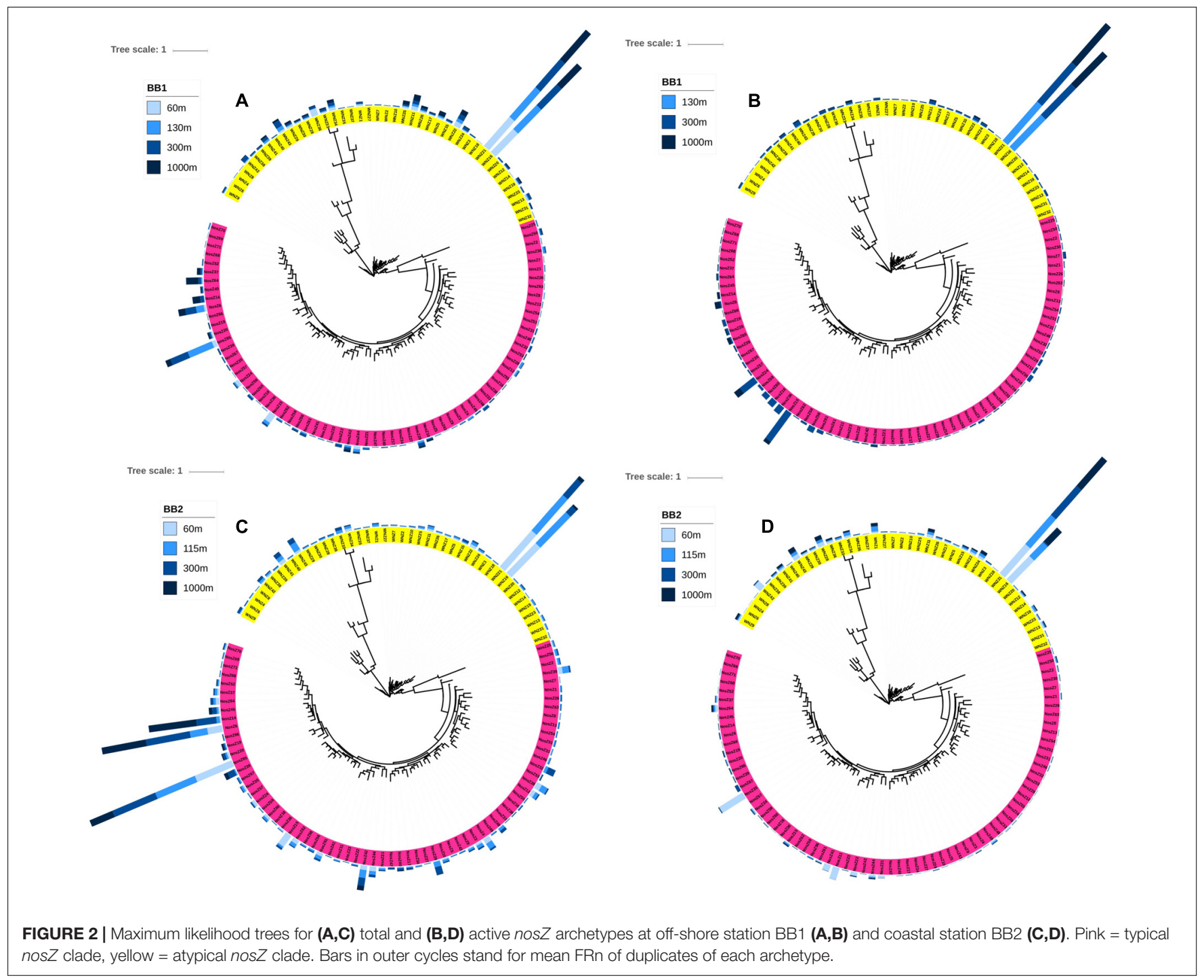

TABLE 1 | $\alpha$-diversities of total (DNA) and active (RNA) nosZ genes at off-shore station BB1 and coastal station BB2.

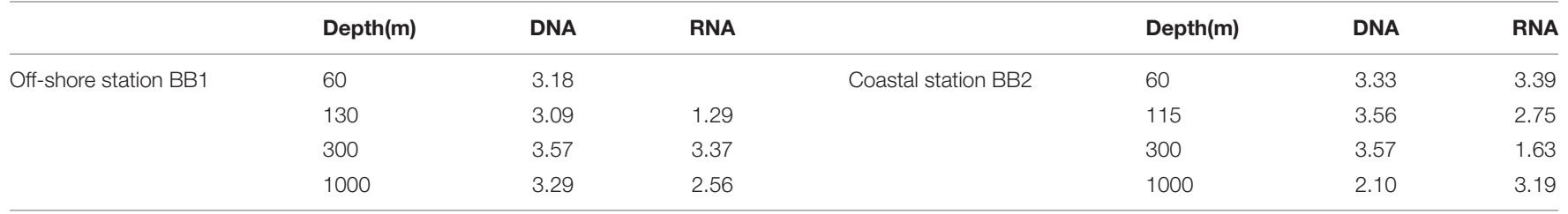

\section{Community Composition of Total and Active nosZ Assemblages}

Functional gene microarrays were used to describe the community composition of nos $Z$ assemblages. FRn values from duplicate microarrays replicated well $\left(r^{2}=0.802-0.997\right)$ (Supplementary Figure 2) and each pair of duplicates clustered together in the DCA plots (Figure 4).

The two-dimensional DCA model including both DNA and RNA microarray results explained $43.7 \%$ of the community composition of nos $Z$ assemblages with $31.6 \%$ explained by the first axis and $12.1 \%$ explained by the second axis (Figure 4A). The clearest pattern was the clear separation of total (filled symbols) and active (open symbols) nos $Z$ assemblages, indicating that they were different from each other. The significance $(P<0.001)$ of the difference between total and active assemblages was confirmed by the dissimilarity test (Table 2). Therefore, the community composition of total and active nos $Z$ assemblages was further analyzed by two DCA models separately to better examine other patterns.

The DCA model of DNA microarray results explained $63.9 \%$ of the composition of the total nos $Z$ assemblage (Figure $4 \mathbf{B}$ ). 

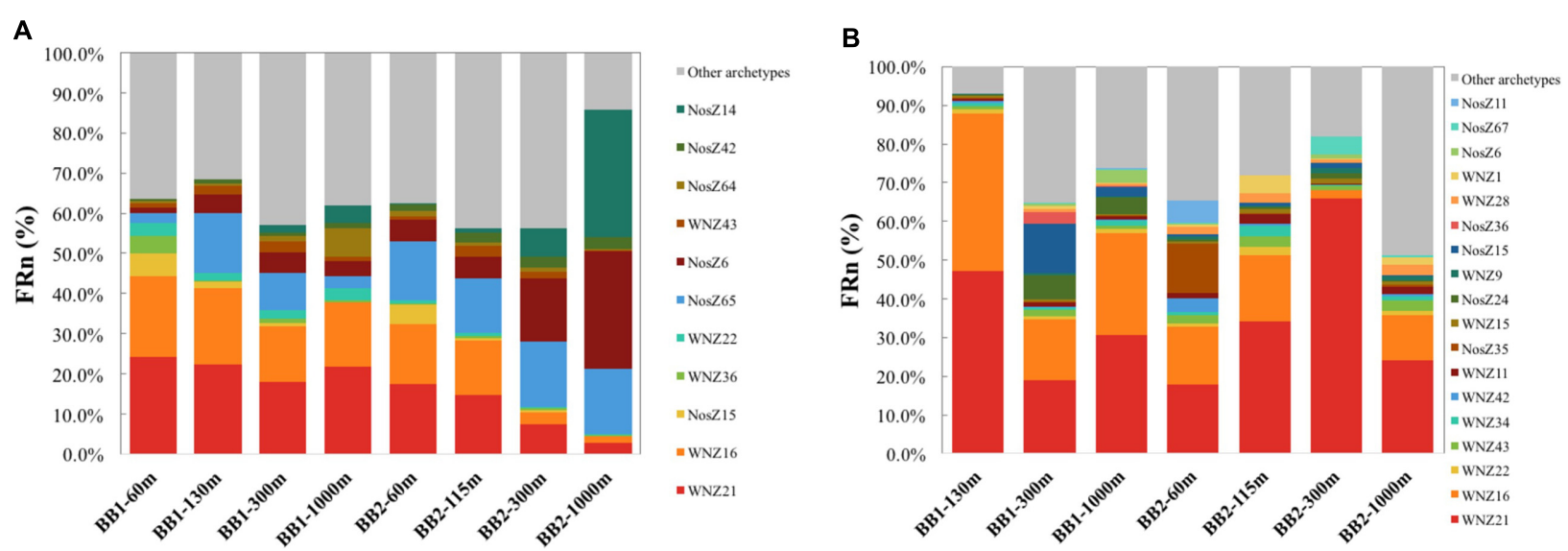

FIGURE 3 | (A) total (DNA) and (B) active (RNA) nosZ archetypes whose FRn signals are among the top five highest in any of the depths at off-shore station BB1 and coastal station BB2.

The total nos $Z$ community composition revealed site difference and $\mathrm{O}_{2}$ dependence. Samples from the same station clustered together in the DCA model, indicating community composition was different between the off-shore station (BB1) and the coastal station (BB2). The site difference was statistically significant $(P<0.001)$ based on the dissimilarity test (Table 2$)$. Besides the geographical pattern, composition of the total nos $Z$ assemblage was also affected by $\mathrm{O}_{2}$ concentration (Figure 4B). Samples from the ODZs clustered together, while samples with higher $\mathrm{O}_{2}$ concentrations were distinct from the ODZ samples and different from each other. $\mathrm{O}_{2}$ concentration of the seawater might not be the most important driver of microbial community composition, however, since the $\mathrm{O}_{2}$ pattern was not captured by either axis of the DCA model.

The DCA model of RNA microarray results explained $40.2 \%$ of the community composition of the active nos $Z$ assemblage (Figure 4C). Significant site difference $(P=0.039)$ of the active community composition was also revealed by the DCA model (Figure 4C) and the dissimilarity test (Table 2). However, the clustering based on $\mathrm{O}_{2}$ concentration that was observed in the total nos $Z$ assemblage was not observed for the active nos $Z$ assemblage.

\section{Environmental Variables Correlated with the Community Composition}

The composition of total and active nos $Z$ assemblages was correlated with different environmental variables based on a Mantel test (Table 3). Relative depth, nitrate concentration, temperature, density (sigma theta) and pressure were significantly related to the $\beta$-diversity of the total nos $Z$ assemblage. However, the $\beta$-diversity of the active nos $Z$ assemblage was significantly related to $\mathrm{N}_{2} \mathrm{O}$ concentration, nitrite concentration and fluorescence. Bottom depth, which was dramatically different between two stations and is a proxy for important ecological differences between the two sites, was a significant factor for both total and active nos $Z$ assemblages.

\section{DISCUSSION}

\section{Abundance and Diversity of nosZ Assemblages}

Oxygen minimum zones are sites of high $\mathrm{N}_{2} \mathrm{O}$ flux to the atmosphere (Law and Owens, 1990; Arévalo-Martínez et al., 2015). $\mathrm{N}_{2} \mathrm{O}$ consuming organisms are the only biological sink for $\mathrm{N}_{2} \mathrm{O}$. Hence their abundance and community composition in the OMZ may be important in understanding the $\mathrm{N}_{2} \mathrm{O}$ flux. The abundance of total and active $\mathrm{N}_{2} \mathrm{O}$ consuming bacteria in the OMZ of the ETSP was estimated by measuring nos $Z$ gene copy number (Figure 1). The relationship between abundance of $\mathrm{N}_{2} \mathrm{O}$ consuming bacteria and depth in this study differed from that of denitrifiers indicated by nirS gene copy number at the same stations (Ji et al., 2015): the abundances of the total and active $\mathrm{N}_{2} \mathrm{O}$ consuming bacteria in the surface water were similar to or higher than those in the ODZs (Figure 1), but the abundance of denitrifiers in the surface water was two orders of magnitude smaller than that in the ODZs. This difference suggests that the two genes represent functionally different groups.

nirS and nos $Z$ also differed in their absolute abundance. The highest abundance of $\mathrm{N}_{2} \mathrm{O}$ consuming bacteria was only a few hundred copies $\mathrm{mL}^{-1}$, which was three orders of magnitude smaller than the highest abundance of denitrifiers measured at the same stations (Ji et al., 2015). It is assumed that both genes are present in the genome as single copy genes, although there are exceptions for nos $Z$ (Sanford et al., 2012). One possible explanation for the differences in both distribution and abundance of the nos $Z$ assemblage and the nirS assemblage is that not all $\mathrm{N}_{2} \mathrm{O}$ consuming bacteria contain the complete denitrification gene sequence (Sanford et al., 2012). The atypical nos $Z$ genes are associated with bacteria that lack the other steps in the conventional denitrification pathway. Notably, bacteria with only nos $Z$ genes but no other denitrification genes were overrepresented in the genomes of marine bacteria compared to other ecosystems (Graf et al., 2014). nirS, however, was 


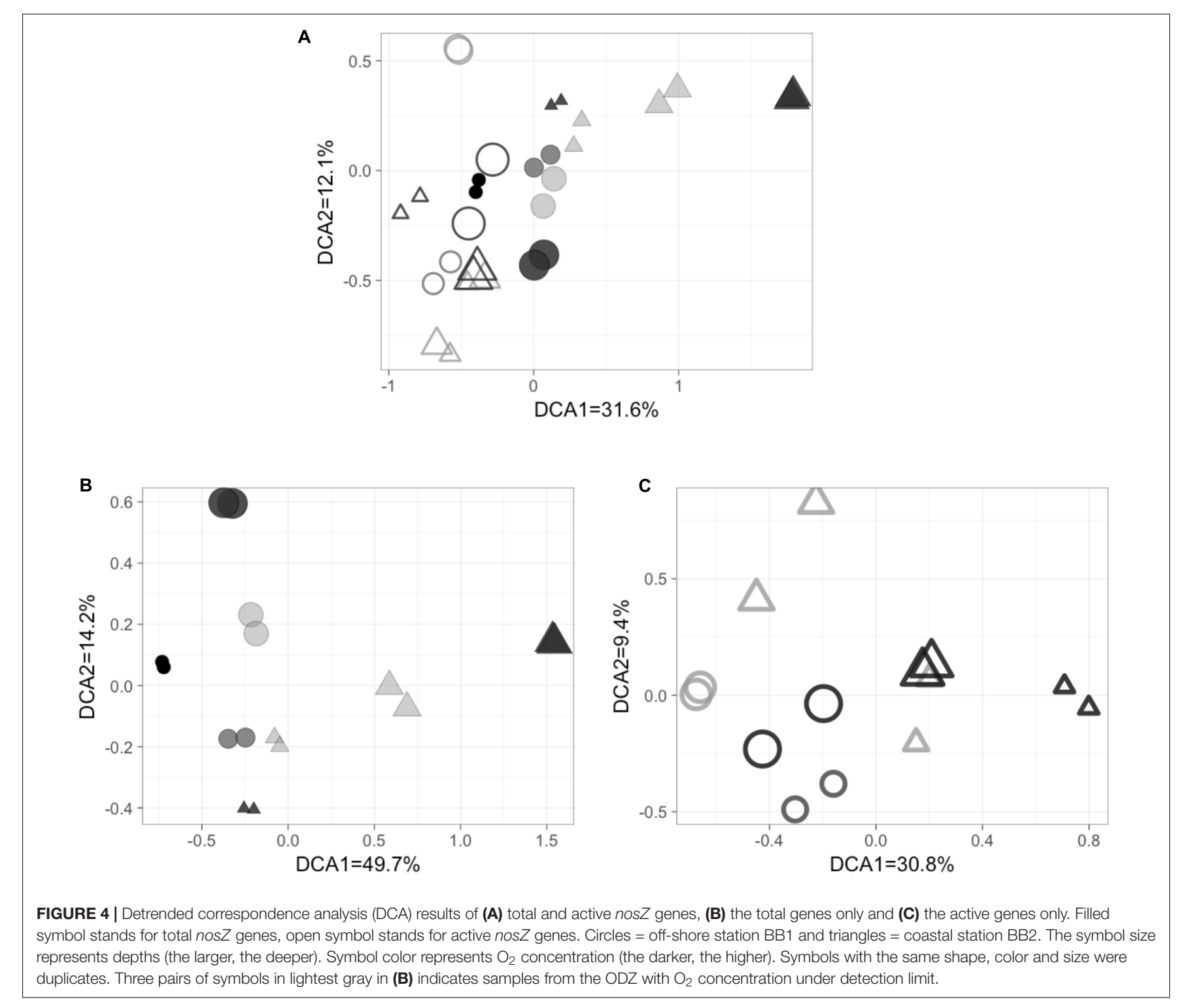

TABLE $2 \mid P$-values of dissimilarity test (adonis).

\begin{tabular}{lccc}
\hline & $\begin{array}{c}\text { DNA and } \\
\text { RNA samples }\end{array}$ & $\begin{array}{c}\text { DNA samples } \\
\text { only }\end{array}$ & $\begin{array}{c}\text { RNA samples } \\
\text { only }\end{array}$ \\
\hline DNA versus RNA & $<0.001$ & - & - \\
Site dependence & 0.034 & $<0.001$ & 0.039 \\
\hline
\end{tabular}

preferentially associated with bacteria that contained a complete denitrification pathway (Graf et al., 2014).

Another contributing factor may be the specificity or bias of the PCR primers. The nos $Z$ primers used in this study were optimized to amplify all known nos $Z$ sequences as of 2006, and should therefore represent the large database of both terrestrial and marine sequences available at the time. However, it is clear that they might underrepresent the atypical $\mathrm{N}_{2} \mathrm{O}$ consuming bacteria, which were not known at the time. The nirS primers used in the previous analysis of these samples (Ji et al., 2015) are potentially biased toward marine sequences (Braker et al., 1998) and may underrepresent more diverse sequences now available from other environments. One way to improve the nos $Z$ coverage is to use multiple primer sets targeting different groups of nos $Z$ archetypes.

The $\mathrm{N}_{2} \mathrm{O}$ consuming bacteria are a small component of the total microbial assemblage, but are still quite diverse (Jones et al., 2013), so they are difficult to characterize by pure culture or metagenomics. The microarray, which was designed specifically to target $\mathrm{N}_{2} \mathrm{O}$ consuming bacteria using more than 100 nos $Z$ gene probes (Figure 2), may be a better tool to capture these underrepresented organisms without cultivation or detection of rare sequences in complex metagenomic datasets. The high reproducibility of microarrays reported previously (Bulow et al., 2008) was confirmed in this study in that duplicates for each sample run on two different microarrays clustered together 
TABLE 3 | Mantel tests between total (DNA) or active (RNA) nosZ genes and environmental factors.

\begin{tabular}{|c|c|c|c|c|}
\hline & \multicolumn{2}{|c|}{ Total nosZ } & \multicolumn{2}{|c|}{ Active nosZ } \\
\hline & $r$ & $P$ & $r$ & $P$ \\
\hline Oxygen & 0.169 & 0.190 & -0.046 & 0.636 \\
\hline Relative Depth ${ }^{1}$ & 0.848 & 0.001 & -0.170 & 0.886 \\
\hline Nitrate & 0.355 & 0.009 & -0.149 & 0.913 \\
\hline Nitrite & 0.090 & 0.178 & 0.300 & 0.019 \\
\hline Nitrous Oxide & -0.089 & 0.684 & 0.415 & 0.014 \\
\hline Temperature & 0.483 & 0.002 & -0.153 & 0.937 \\
\hline Ammonium & 0.155 & 0.234 & -0.008 & 0.458 \\
\hline Salinity & 0.258 & 0.069 & -0.165 & 0.941 \\
\hline Sigma Theta ${ }^{2}$ & 0.439 & 0.007 & -0.088 & 0.774 \\
\hline Bottom Depth & 0.320 & 0.001 & 0.255 & 0.012 \\
\hline Pressure & 0.492 & 0.003 & -0.168 & 0.949 \\
\hline Fluorescence & 0.059 & 0.290 & 0.320 & 0.015 \\
\hline
\end{tabular}

${ }^{1}$ Relative depth was calculated by dividing measured depth by the bottom depth of each station. ${ }^{2}$ Sigma Theta was density calculated with in situ salinity and potential temperature at zero pressure. Bolded $P$ values indicate significant correlation $(P<0.05)$.

in DCA (Figure 4) and had high $r^{2}$ of linear regressions (Supplementary Figure 2).

Based on the FRn values of diverse nos $Z$ archetypes determined by microarray hybridization (Figure 2), a very limited number of archetypes dominated the total or the active assemblages. Moreover, the top five active archetypes accounted for larger percentage of the assemblage than that of the total archetypes (Figure 3), consistent with the less diverse active assemblage compared to the total assemblage (Table 1). These findings imply that although the total nos $Z$ assemblage is very diverse, a few nos $Z$ archetypes might be the major contributors of $\mathrm{N}_{2} \mathrm{O}$ consumption at the study sites. The relative abundance of active archetypes, however, might uncouple that of enzymes of different archetypes and/or the contribution of different archetypes to the $\mathrm{N}_{2} \mathrm{O}$ consumption rate due to different stabilities of enzymes from different archetypes.

\section{Total and Active Community Compositions and Their Controlling Environmental Variables}

The active nos $Z$ assemblage was different from the total assemblage in both abundance profiles and community composition as detected by $\mathrm{qPCR}$ and nos $Z$ microarray hybridization analysis, respectively. The highest abundance of the total $\mathrm{N}_{2} \mathrm{O}$ consuming bacteria indicated by nos $Z$ DNA copy number was $636.4( \pm 28.3)$ copies $\mathrm{mL}^{-1}$ in the sample from the ODZ $(115 \mathrm{~m})$ at station BB2, but the abundance of the active bacteria in the same sample was only $21.1( \pm 5.2)$ copies $\mathrm{mL}^{-1}$ (Figure 1). In the sample from oxygenated surface seawater $(60 \mathrm{~m})$ at station $\mathrm{BB} 1$, the abundance of the active $\mathrm{N}_{2} \mathrm{O}$ consuming bacteria was $604.6( \pm 103.7)$ copies $\mathrm{mL}^{-1}$, but the abundance of the total bacteria was only $357.2( \pm 12.5)$ copies $\mathrm{mL}^{-1}$ (Figure 1).
Significant differences between the community composition of total and active $\mathrm{N}_{2} \mathrm{O}$ consuming bacteria were indicated by the results of DCA and dissimilarity test (Figure 4A; Table 2). The different community composition was attributed to the differences in the distribution of FRn of more than 100 archetypes, especially the dominant ones. NosZ6 and NosZ65 were dominant in the total nos $Z$ assemblage but were minor components in the active assemblage. NosZ42 was the most abundant archetype in the total nos $Z$ assemblage from the lower oxycline $(1000 \mathrm{~m})$ at station $\mathrm{BB} 2$, but was not among the top five archetypes of the active assemblage. These differences between active and total nos $Z$ communities are consistent with observations from soil and salt marsh sediments in which the active component of the microbial assemblage was apparently more responsive to environmental conditions (Barnard et al., 2013; Kearns et al., 2016).

Despite the differences between the total and the active $\mathrm{N}_{2} \mathrm{O}$ consuming assemblages, their distributions both depended on geographic location. The composition of total and active nos $Z$ assemblages was significantly different between the coastal and the off-shore stations as indicated by the results of DCA and dissimilarity test. Since the two stations shared similar dominant nos $Z$ archetypes, the geographical divergence mainly reflected differences among the large number of rare archetypes between the two stations. The more negative $\mathrm{N}^{*}$ at the coastal station BB2 (Supplementary Table 1) indicates more intense nitrogenloss fueled by more organic matter. The different amount of organic matter, which supports the metabolism of heterotrophic nos $Z$ bacteria, might partially contribute to the geographical differences of nos $Z$ assemblages. Geographical differences might also result from different nutrient sources at the two stations, since their distance to the sediment (bottom depth) and to the shore were dramatically different. The dependence of geographic location was also observed for ammonia oxidizing archaea (Peng et al., 2013) and for nirS denitrifiers (Jayakumar et al., 2013) in the ETSP and Arabian Sea OMZs.

In addition to geographical patterns, the total and active assemblages were correlated with different environmental variables (Table 3). Depth and environmental parameters that co-varied with depth (including temperature, density and pressure) were major drivers of the $\beta$-diversity of the total $\mathrm{N}_{2} \mathrm{O}$ consuming assemblages, implying different organisms coexist in the water column by occupying different ecological niches. However, $\mathrm{N}_{2} \mathrm{O}$ concentration difference was a major driver of the $\beta$-diversity of the active nos $Z$ assemblages, implying the active nos $Z$ community was a better indicator for $\mathrm{N}_{2} \mathrm{O}$ consumption potential.

\section{nosZ Assemblage in Oxygenated Seawater}

The role of the nos $Z$ assemblage in oxygenated seawater has been ignored because $\mathrm{N}_{2} \mathrm{O}$ consumption is considered the least oxygen tolerant anaerobic step in the conventional denitrification pathway (Zumft, 1997). However, nosZ genes were abundant in oxygenated surface water in the Southern Indian Ocean (Raes et al., 2016) and nos $Z$ mRNAs were detected in the 
oxic regions in the Arabian Sea (Wyman et al., 2013). Our study confirmed that a nos $Z$ assemblage was not only present but also active in oxygenated surface water in the OMZ of the ETSP. In particular, atypical nos $Z$ archetypes, usually associated with $\mathrm{N}_{2} \mathrm{O}$ consuming bacteria lacking a complete denitrification pathway, were present and active in surface waters. In addition, the most abundant archetypes of total and active nos $Z$ communities were both atypical nos $Z$ archetypes (WNZ21 and WNZ16), implying the significant contribution of atypical archetypes to the nos $Z$ communities and the necessity to consider atypical archetypes while analyzing the potential of $\mathrm{N}_{2} \mathrm{O}$ consumption.

$\mathrm{N}_{2} \mathrm{O}$ reductase enzymes from denitrifiers had very low $\mathrm{O}_{2}$ tolerance (Bonin et al., 1989; Körner and Zumft, 1989); on the contrary, nos $Z$ assemblages were detected in the oxygenated surface waters and $\mathrm{O}_{2}$ concentration was not significantly correlated with the active microbial community, as indicated by DCA and Mantel test. The survival of $\mathrm{N}_{2} \mathrm{O}$ consuming bacteria in oxic layers and their $\mathrm{O}_{2}$-independence might be attributed to anoxic micro-environments created by phytoplankton microaggregates or particles. Free-living and particle-associated microbes from the same seawater sample can have different community compositions (Delong et al., 1993). More specifically, a recent study in the OMZ of the ETSP showed that nos $Z$ mRNAs were 28-fold more abundant on particles $(>1.6 \mu \mathrm{m})$ compared to free-living microbes $(0.2-1.6 \mu \mathrm{m})$ (Ganesh et al., 2015). Additionally, nosZ mRNA co-occurred with the cyanobacterium Trichodesmium in oxic water in the Arabian Sea (Wyman et al., 2013). Consistently, fluorescence, a proxy for chlorophyll a, was significantly correlated with the $\beta$-diversity of the active nos $Z$ assemblages in this study (Table 3).

The active nos $Z$ community in oxygenated surface water might capture $\mathrm{N}_{2} \mathrm{O}$ produced in deeper seawater and thus reduce the flux into the atmosphere. Thus, evaluating the nos $Z$ community is essential to the prediction of the oceanic $\mathrm{N}_{2} \mathrm{O}$ emissions. Moreover, the oceanic $\mathrm{N}_{2} \mathrm{O}$ emissions represent net fluxes, which are controlled by both $\mathrm{N}_{2} \mathrm{O}$ production and $\mathrm{N}_{2} \mathrm{O}$ consumption. Some $\mathrm{N}_{2} \mathrm{O}$ flux models (Suntharalingam and Sarmiento, 2000; Martinez-Rey et al., 2015; Trimmer et al., 2016) do not parameterize $\mathrm{N}_{2} \mathrm{O}$ consumption, and other models either consider $\mathrm{N}_{2} \mathrm{O}$ consumption only in suboxic or anoxic waters (Cornejo and Farías, 2012; Babbin et al., 2015) or estimate $\mathrm{N}_{2} \mathrm{O}$ consumption assuming it is constrained by $\mathrm{O}_{2}$ concentration (Zamora et al., 2012). Failing to consider the $\mathrm{O}_{2}$-independent, non-denitrification $\mathrm{N}_{2} \mathrm{O}$ consumption potential in these $\mathrm{O}_{2}$ forcing models might contribute to their uncertainty and the variation among different models. Additionally, the $\mathrm{N}_{2} \mathrm{O}$ consuming organisms have not been fully investigated. Besides denitrifiers and atypical $\mathrm{N}_{2} \mathrm{O}$ consuming bacteria analyzed in this study, other organisms (Trichodesmium and Crocosphaera) also exhibited $\mathrm{N}_{2} \mathrm{O}$ consuming capacity under laboratory conditions (Farías et al., 2013), suggesting that their significance in the environment warrants further investigation.

\section{CONCLUSION}

The results described above support two (1 and 3) of the initial hypotheses. (1) Compositions of total and active nos $Z$ assemblages were different between the coastal station and the off-shore station mainly due to their dramatic differences of distance to the sediment and to the shore, which are very likely to result in different environmental conditions (i.e., different phytoplankton assemblages, different nutrients and organic matter). (2) The abundances of total and active $n o s Z$ assemblages in oxygenated seawater were similar to or larger than those in the ODZs, implying the potential for $\mathrm{N}_{2} \mathrm{O}$ consumption even in oxygenated surface water. Atypical nos $Z$ archetypes, which may lack a complete denitrification pathway, dominated both total and active nos $Z$ assemblages. (3) The total and active nos $Z$ assemblages were significantly different from each other. The community composition of the total nos $Z$ assemblage showed $\mathrm{O}_{2}$ dependence and shifted along depth gradients and environmental gradients associated with depth, but fluorescence, $\mathrm{N}_{2} \mathrm{O}$ and nitrite concentration were significantly correlated with the composition of the transcriptionally active community. We conclude that the difference between active and total nos $Z$ assemblages may be related to differential response to environmental conditions by different components of the diverse natural assemblage and that the presence of nos $Z$ assemblage in surface waters should be investigated to determine their actual $\mathrm{N}_{2} \mathrm{O}$ reduction capabilities.

\section{AUTHOR CONTRIBUTIONS}

$\mathrm{XS}$ and BW designed the experiments. AJ and BW collected samples. XS and AJ performed experiments. XS analyzed the data. $\mathrm{XS}$ and BW wrote the paper.

\section{FUNDING}

This paper was supported by an NSF grant to BW and AJ (OCE-1029951).

\section{ACKNOWLEDGMENT}

We would like to acknowledge all scientists and the crew of the $R / V$ Nathaniel B. Palmer for assistance in sample collection.

\section{SUPPLEMENTARY MATERIAL}

The Supplementary Material for this article can be found online at: http://journal.frontiersin.org/article/10.3389/fmicb. 2017.01183/full\#supplementary-material 


\section{REFERENCES}

Arévalo-Martínez, D. L., Kock, A., Löscher, C. R., Schmitz, R. A., and Bange, H. W. (2015). Massive nitrous oxide emissions from the tropical South Pacific Ocean. Nat. Geosci. 8, 530-533. doi: 10.1038/ngeo2469

Babbin, A. R., Bianchi, D., Jayakumar, A., and Ward, B. B. (2015). Rapid nitrous oxide cycling in the suboxic ocean. Science 348, 1127-1129. doi: 10.1126/ science.aaa 8380

Babbin, A. R., Keil, R. G., Devol, A. H., and Ward, B. B. (2014). Oxygen control nitrogen loss in the ocean. Science 344, 406-408. doi: 10.1126/science.1248364

Barnard, R. L., Osborne, C. A., and Firestone, M. K. (2013). Responses of soil bacterial and fungal communities to extreme desiccation and rewetting. ISME J. 7, 2229-2241. doi: 10.1038/ismej.2013.104

Bonin, P., Gilewicz, M., and Bertrand, J. C. (1989). Effects of oxygen on each step of denitrification on Pseudomonas nautica. Can. J. Microbiol. 35, 1061-1064. doi: $10.1139 / \mathrm{m} 89-177$

Braker, G., Fesefeldt, A., and Witzel, K.-P. (1998). Development of PCR primer systems for amplification of nitrite reductase genes (nirK and nirS) to detect denitrifying bacteria in environmental samples. Appl. Environ. Microbiol. 64, 3769-3775.

Bulow, S. E., Francis, C. A., Jackson, G. A., and Ward, B. B. (2008). Sediment denitrifier community composition and nirS gene expression investigated with functional gene microarrays. Environ. Microbiol. 10, 3057-3069. doi: 10.1111/j. 1462-2920.2008.01765.x

Castro-González, M., Ulloa, O., and Farías, L. (2015). Structure of denitrifying communities reducing $\mathrm{N}_{2} \mathrm{O}$ at suboxic waters off northern Chile and Perú. Rev. biol. Mar. Ocean. 50, 95-110. doi: 10.4067/S0718-19572015000100008

Codispoti, L. A. (2010). Interesting times for marine $\mathrm{N}_{2}$ O. Science 327, 1339-1340. doi: $10.1126 /$ science.1184945

Cornejo, M., and Farías, L. (2012). Following the $\mathrm{N}_{2} \mathrm{O}$ consumption in the oxygen minimum zone of the eastern South Pacific. Biogeosciences 9, 3205-3212. doi: 10.5194/bg-9-3205-2012

Dalsgaard, T., Thamdrup, B., Farías, L., and Peter Revsbech, N. (2012). Anammox and denitrification in the oxygen minimum zone of the eastern South Pacific. Limnol. Oceanogr. 57, 1331-1346. doi: 10.4319/lo.2012.57.5.1331

Delong, E. F., Franks, D. G., and Alldredge, A. L. (1993). Phylogenetic diversity of aggregate-attached vs. free-living marine bacterial assemblages. Limnol. Oceanogr. 38, 924-934. doi: 10.4319/lo.1993.38.5.0924

Deutsch, C., Key, R. M., Sarmiento, J. L., and Ganachaud, A. (2001). Denitrification and $\mathrm{N}_{2}$ fixation in the Pacific Ocean. Glob. Biogeochem. Cycles 15, 483-506. doi: 10.1029/2000GB001291

Farías, L., Castro-González, M., Cornejo, M., Charpentier, J., Faúndez, J., Boontanon, N., et al. (2009). Denitrification and nitrous oxide cycling within the upper oxycline of the eastern tropical South Pacific oxygen minimum zone. Limnol. Oceanogr. 54, 132-144. doi: 10.4319/lo.2009.54.1.0132

Farías, L., Faúndez, J., Fernández, C., Cornejo, M., Sanhueza, S., and Carrasco, C. (2013). Biological $\mathrm{N}_{2} \mathrm{O}$ fixation in the Eastern South Pacific Ocean and marine cyanobacterial cultures. PLoS ONE 8:e63956. doi: 10.1371/journal.pone. 0063956

Ganesh, S., Bristow, L. A., Larsen, M., Sarode, N., Thamdrup, B., and Stewart, F. J. (2015). Size-fraction partitioning of community gene transcription and nitrogen metabolism in a marine oxygen minimum zone. ISME J. 9, 2682-2696. doi: 10.1038 /ismej.2015.44

Graf, D. R. H., Jones, C. M., and Hallin, S. (2014). Intergenomic comparisons highlight modularity of the denitrification pathway and underpin the importance of community structure for $\mathrm{N}_{2} \mathrm{O}$ emissions. PLoS ONE 9:e114118. doi: 10.1371/journal.pone.0114118

Henry, S., Bru, D., Stres, B., Hallet, S., Philippot, L., Burgundy, I., et al. (2006). Quantitative detection of the nosZ gene, encoding nitrous oxide reductase, and comparison of the abundances of $16 \mathrm{~S}$ rRNA, narG, nirK, and nosZ genes in soils. Appl. Environ. Microbiol. 72, 5181-5189. doi: 10.1128/AEM.00231-06

IPCC (2007). "Changes in atmospheric constituents and in radiative forcing," in Climate Change 2007: The Physical Science Basis. Contribution of Working Group I to the Fourth Assessment Report of the Intergovernmental Panel on Climate Change (Cambridge: Cambridge University Press). doi: 10.1103/ PhysRevB.77.220407

Jayakumar, A., Peng, X., and Ward, B. B. (2013). Community composition of bacteria involved in fixed nitrogen loss in the water column of two major oxygen minimum zones in the ocean. Aquat. Microb. Ecol. 70, 245-259. doi: 10.3354/ame01654

Ji, Q., Babbin, A., Jayakumar, A., Oleynik, S., and Ward, B. B. (2015). Nitrous oxide production by nitrification and denitrification in the Eastern Tropical South Pacific oxygen minimum zone. Geophys. Res. Lett. 42, 755-764. doi: 10.1002/2015GL065934

Jones, C. M., Graf, D. R., Bru, D., Philippot, L., and Hallin, S. (2013). The unaccounted yet abundant nitrous oxide-reducing microbial community: a potential nitrous oxide sink. ISME J. 7, 417-426. doi: 10.1038/ismej.20 12.125

Kearns, P. J., Angell, J. H., Feinman, S. G., and Bowen, J. L. (2015). Long-term nutrient addition differentially alters community composition and diversity of genes that control nitrous oxide flux from salt marsh sediments. Estuar. Coast. Shelf Sci. 154, 39-47. doi: 10.1016/j.ecss.2014.12.014

Kearns, P. J., Angell, J. H., Howard, E. M., Deegan, L. A., Stanley, R. H. R., Bowen, J. L., et al. (2016). Nutrient enrichment induces dormancy and decreases diversity of active bacteria in salt marsh sediments. Nat. Commun. 7:12881. doi: $10.1038 /$ ncomms 12881

Körner, H., and Zumft, W. G. (1989). Expression of denitrification enzymes in response to the dissolved oxygen level and respiratory substrate in continuous culture of Pseudomonas stutzeri. Appl. Environ. Microbiol. 55, 1670-1676.

Law, C. S., and Owens, N. J. P. (1990). Significant flux of atmospheric nitrous oxide from the northwest Indian Ocean. Nature 346, 826-828. doi: 10.1038/3468 $26 \mathrm{a} 0$

Martinez-Rey, J., Bopp, L., Gehlen, M., Tagliabue, A., and Gruber, N. (2015). Projections of oceanic $\mathrm{N}_{2} \mathrm{O}$ emissions in the 21st century using the IPSL Earth system model. Biogeosciences 12, 4133-4148. doi: 10.5194/bg-12-4133-2015

Naqvi, S. W., Jayakumar, D. A., Narvekar, P. V., Naik, H., Sarma, V. V., D'Souza, W., et al. (2000). Increased marine production of $\mathrm{N} 2 \mathrm{O}$ due to intensifying anoxia on the Indian continental shelf. Nature 408, 346-349. doi: 10.1038/35042551

Nicholls, J. C., Davies, C. A., and Trimmer, M. (2007). High-resolution profiles and nitrogen isotope tracing reveal a dominant source of nitrous oxide and multiple pathways of nitrogen gas formation in the central Arabian Sea. Limnol. Oceanogr. 52, 156-168. doi: 10.4319/lo.2007.52.1.0156

Peng, X., Jayakumar, A., and Ward, B. B. (2013). Community composition of ammonia-oxidizing archaea from surface and anoxic depths of oceanic oxygen minimum zones. Front. Microbiol. 4:177. doi: 10.3389/fmicb.2013. 00177

Raes, E. J., Bodrossy, L., Van De Kamp, J., Holmes, B., Hardman-Mountford, N., Thompson, P. A., et al. (2016). Reduction of the powerful greenhouse gas $\mathrm{N}_{2} \mathrm{O}$ in the south-eastern Indian Ocean. PLoS ONE 11:e0145996. doi: 10.1371/ journal.pone.0145996

Ravishankara, A. R., Daniel, J. S., and Portmann, R. W. (2009). Nitrous oxide (N2O): the dominant ozone-depleting substance emitted in the 21st century. Science 326, 123-125. doi: 10.1126/science.1176985

Revsbech, N. P., Larsen, L. H., Gundersen, J., Dalsgaard, T., Ulloa, O., and Thamdrup, B. (2009). Determination of ultra-low oxygen concentrations in oxygen minimum zones by the STOX sensor. Limnol. Oceanogr. Methods 7, 371-381. doi: 10.4319/lom.2009.7.371

Sanford, R. A., Wagner, D. D., Wu, Q., Chee-Sanford, J. C., Thomas, S. H., CruzGarcia, C., et al. (2012). Unexpected nondenitrifier nitrous oxide reductase gene diversity and abundance in soils. Proc. Natl. Acad. Sci. U.S.A. 109, 19709-19714. doi: 10.1073/pnas.1211238109

Song, L., Ren, L., Li, X., Yu, D., Yu, Y., Wang, X., et al. (2013). Complete genome sequence of Marinobacter sp. BSs20148. Genome Announc. 1:e00236-13. doi: 10.1128/genomeA.00236-13

Suntharalingam, P., and Sarmiento, J. L. (2000). Factors governing the oceanic nitrous oxide distribution: simulations with an ocean genera circulation model. Glob. Biogeochem. Cycles 14, 429-454. doi: 10.1029/1999GB900032

Trimmer, M., Chronopoulou, P.-M., Maanoja, S. T., Upstill-Goddard, R. C., Kitidis, V., and Purdy, K. J. (2016). Nitrous oxide as a function of oxygen and archaeal gene abundance in the North Pacific. Nat. Commun. 7:13451. doi: 10.1038/ncomms13451

UNESCO (1994). Protocols for the Joint Global Ocean Flux Study (JGOFS) Core Measurements, ed. Intergovernmental Oceanographic Commission, United Nations Educational, Scientific and Cultural Organization. Paris: UNESCO. 
Ward, B. B., and Bouskill, N. J. (2011). "The utility of functional gene arrays for assessing community composition, relative abundance, and distribution of ammonia- oxidizing bacteria and archaea," in Methods in Enzymology, 1st Edn, Vol. 496, eds M. G. Klotz and L. Y. Stein (Burlington, NJ: Elsevier Inc.), 373-396. doi: 10.1016/B978-0-12-386489-5.00015-4

Ward, B. B., Tuit, C. B., Jayakumar, A., Rich, J. J., Moffett, J., and Naqvi, S. W. A. (2008). Organic carbon, and not copper, controls denitrification in oxygen minimum zones of the ocean. Deep. Res. I Oceanogr. Res. Pap. 55, 1672-1683. doi: 10.1016/j.dsr.2008.07.005

Wyman, M., Hodgson, S., and Bird, C. (2013). Denitrifying alphaproteobacteria from the Arabian Sea that express nosZ, the gene encoding nitrous oxide reductase, in oxic and suboxic waters. Appl. Environ. Microbiol. 79, 2670-2681. doi: 10.1128/AEM.03705-12

Zamora, L. M., Oschlies, A., Bange, H. W., Huebert, K. B., Craig, J. D., Kock, A., et al. (2012). Nitrous oxide dynamics in low oxygen regions of the
Pacific: insights from the MEMENTO database. Biogeosciences 9, 5007-5022. doi: 10.5194/bg-9-5007-2012

Zumft, W. G. (1997). Cell biology and molecular basis of denitrification. Microbiol. Mol. Biol. Rev. 61, 533-616.

Conflict of Interest Statement: The authors declare that the research was conducted in the absence of any commercial or financial relationships that could be construed as a potential conflict of interest.

Copyright (c) 2017 Sun, Jayakumar and Ward. This is an open-access article distributed under the terms of the Creative Commons Attribution License (CC BY). The use, distribution or reproduction in other forums is permitted, provided the original author(s) or licensor are credited and that the original publication in this journal is cited, in accordance with accepted academic practice. No use, distribution or reproduction is permitted which does not comply with these terms. 